\title{
VOU POSTAR NO INSTAGRAM! \\ O NARCISISMO E A FOTOGRAFIA CONTEMPORÂNEA
}

\author{
Amanda M. P. Leite \\ UFT-TO
}

\section{Resumo}

Diariamente somos submetidos a enxurradas de fotografias. Redes sociais e aplicativos permitem que compartilhemos imagens sobre a vida e seus os acontecimentos, mas o que elas comunicam? o texto explora a questão do Narcisismo, o fetichismo visual contemporâneo e as possibilidades de tomar a fotografia como um dispositivo aberto ao ver e ao pensar. Ao produzir visualidades (fotógrafos amadores e profissionais) podem transitar entre ordem e caos, temor e vontade, mistério e imaginação na tentativa de desterritorializar o olhar, deslocar o sujeito e romper com um comportamento domesticado diante da imagem. A fotografia pode desassossegar o olhar e nos convidar a perceber as imagens que nos cercam de outros modos.

\section{Palavras-chave:}

Artes Visuais; fotografia; fotomontagem; vídeo; Samy Sfoggia.

\section{Resumen}

Diariamente estamos sometidos a inundaciones fotografícas. Redes sociales y aplicativos nos permiten compartir imágenes de la vida y sus acontecimentos. Que es lo que comunican? El texto explora la cuestión del narcisismo, el fetichismo visual contemporáneoy las possibilidades de tomar la fotografía como un dispositivo abierto para ver y pensar. Mediante la producción de visualidades (fotógrafos aficionados y profesionales) pueden moverse entre el orden y el caos, el miedo y el deseo, el misterio y la imaginación para tratar de desterritorializar la mirada, deslocar el sujeto, y romper con un comportamiento dócil ante la imagen. La fotografía puede perturbar la mirada y nos invitar a percibir las imágenes que nos rodean de otras maneras.

Palabra-chave:

Fotografia; fetichismo; narcisismo; ver; piensar.

\section{Abstract}

Daily we are subjected to flurries of photography's. Social networks and apps allow us to share images about life and its happenings. However, what do they communicate? The text explores the issue of Narcissism, the contemporary visual fetishism and the possibilities of taking photography as an apparatus open to seeing and thinking. By producing visualities (amateur and professional photographers), they can move between order and chaos, fear and will, mystery and imagination in an attempt to deterritorialize the look, to displace the subject and to break with a domesticated behavior before the image. Photography can make our eyes uncomfortable and invite us to perceive the images that surround us in other ways.

Keywords:

Visual arts; photography; photomontage; video; Samy Sfoggia

“O fotógrafo é o ser contemporâneo por excelência; através dos seus olhos, o agora se torna passado"

(SONTAG, 2004, p. 82)

Que fotografias nos (co)movem hoje? Fotografias de artistas, catástrofes, eventos beneficentes, comerciais, expedições, exposições? Fotografias amadoras estampadas em redes sociais e sites populares? Que imagem é capaz de atravessar ou mesmo pausar o nosso olhar na velocidade dos tempos que corre? Se por um lado estas questões são amplas, por outro, mostram que a fotografia se situa num lugar de passagem, está aberta a uma infinidade de percepções, leituras e críticas. É, sobretudo, um dispositivo de controle e de poder. Por isso a relevância de percebermos como a fotografia está se difundindo, mais precisamente não como arte, mas como um ritual, uma ansiedade contemporânea de nos colocar em evidência. 
A massificação imagética de nós mesmos nos acompanha da infância até o fim dos nossos dias. Nos álbuns de família, por exemplo, encontramos diversos modos de como às pessoas narram a própria existência. As fotografias compõem recortes de nós. São imagens análogas dos que estão presentes, assim como permitem recordar àquilo que resta dos que faleceram ou dos que estão distantes. Lidávamos antes com a fotografia impressa, com o registro gravado em papel. Agora as fotografias são disponibilizadas por via digital. Os álbuns de família podem facilmente ser vistos por qualquer pessoa que tenha acesso a uma conexão direta à Internet. Estas variações acabam por estabelecer outros códigos sociais.

Metaforicamente Susan Sontag (2004, p. 19) acaba por associar o comportamento do fotógrafo ao do turista que, ao viajar, sentese obrigado a levar uma câmera fotográfica para registrar (e provar) que algo aconteceu ou mesmo que a viagem se realizou, de que a programação foi cumprida, de que houve diversão. Para a autora, viajar se torna uma estratégia de acumular fotos [...] os turistas, em sua maioria, sentem-se compelidos a pôr a câmera entre si mesmos e tudo de notável que encontram. É como se a pausa para o registro Ihes autorizasse seguir adiante.

Mas, o que move o fetichismo visual contemporâneo na busca por instantâneos? Um voyeurismo desenfreado? Um novo modo de experienciar? A aflição por comprovar que conhecemos alguém famoso? Que compramos algo novo? Que estamos cozinhando, lendo um best seller, ou simplesmente, que não estamos fazendo nada? Por que tirar fotos e, mais que isso, tornar visíveis imagens tão corriqueiras?

Aqui não importa entender as causas desse gesto contemporâneo, mas, saber que as fotografias podem revelar eventos de nós mesmos. Eis a foto! Eis a eleição de um acontecimento. Eis a memória! Eis o mundo-imagem que promete sobreviver a todos nós ${ }^{1}$. Eis o fotógrafo, o jogo e o espectador. (O triunfo da fotografia?) O fotógrafo se desafia na medida em que escava temas já conhecidos para, a partir deles, descobrir novas perspectivas. A busca incessante está em fotografar (quem sabe) o avesso das coisas. Um olhar nômade que encontra na fotografia a sua expressão. Para além de mera representação, a fotografia é uma ficção capaz de ampliar a dimensão poética, ética e estética do olhar, dos modos de ver e pensar.

A velocidade com que as imagens são publicadas pelas tecnologias digitais parece configurar uma via de mão dupla onde, não negamos o impacto que as imagens têm, constituindo-se como um dos mais importantes artefatos de alfabetização do indivíduo na leitura do mundo-imagem, e por outro lado, alertamos sobre a necessidade de se pensar e se problematizar o uso das imagens e os modos como lidamos com elas em nosso cotidiano. Uma reflexão que tome as imagens para além de seu fim. Não significa pensar a imagem pela imagem, mas potencializá-la como um código social que ultrapassa os limiares da linguagem visual.

Ao pensar sobre o fetichismo visual contemporâneo vemos que o fotógrafo (profissional e amador) age como um colecionador, um poeta, um detetive, um invasor que apreende pela câmera as paisagens e cenas que conhece. É ele quem percorre o tempo e cria o passado (o isto foi para lembrar Barthes (1984) uma vez capturado o agora-passado é arquivo móvel, papel portátil, um produto da fábrica de retratos ou ainda uma parcela da realidade empacotada (pocket) que tende a parecer invisível dado o arrastão imagético a que somos sucedidos. Tomar, portanto, a ficção e, neste caso, a fotografia como um dispositivo poético para se pensar nossa própria existência é um desafio atual. Pensar com o caos, com fissuras, com inconstâncias... Ao eleger a poesia como pensamento da própria existência Garcia² (2006, p.140) recorda que:

[...] ela, enquanto máquina rítmica, recorta o caos. Este caos é aceso por meio do olhar, por meio do enfrentamento insuportável para o homem, o qual, quer pela sua necessidade de controle, quer pelas necessidades de sobrevivência no convencional, tende a abrir guarda-sóis, até que o poeta - até que a criação enquanto heterogênese - volte a realizar, tal como Lúcio Fontana, a seu modo, em seus experimentos espaciais multidimensionais, rasgões no toldo que o protege do sol (ainda que novos remendos venham a ser feitos)

O fotógrafo-poeta (artista, professor e/ ou estudante) é aquele que transita entre 
ordem e caos; temor e vontade; mistério e imaginação - duos que se retroalimentam sucessivamente. A ficção necessita provocar rasgões, desterritorializar o olhar, deslocar o sujeito entre as fantasmagorias impressas num jogo cadencioso, capaz de romper com um comportamento domesticado diante da fotografia. O registro do instantâneo e/ou a micro parcela de tempo que separa o olhar e o disparo do obturador é capturado, multiplicado, torna-se vertigem nas mãos do fotógrafo e pode desassossegar nossa forma de ver e pensar com/entre/a partir de uma fotografia.

Vemos pessoas envelhecer nas fotos. O tempo assusta o rosto que sorri. Trabalhadores, crianças, professores, palhaços do circo, gente da rua... todos tornam-se alegorias, nuvens de fumaça, vida que jaz... a fotografia é o inventário da mortalidade. Basta, agora, um toque do dedo para dotar um momento de ironia póstuma (SONTAG, 2004, p. 85). Talvez, o que move o fotógrafo continue sendo os segredos de cada fotografia, seus trançados, sua verba ficcional e fragmentada. Aquilo que se dá visível e que sobrevive ao tempo. É a convergência da fábula em linhas, traços e cores.

Para lembrar Garcia (2006, p. 142) segredo e mistério habitam o espaço entre o efêmero e o eterno. Neste sentido, o que constitui o poeta como tal não é a resposta, mas a pergunta, então, se a fotografia hoje é objeto de consumo, que tipo de fotografias consumimos? Um tipo de vanguarda, de pós-verdade que deseja deslocar tradições? Ao apresentar o vazio, o caos, o Outro, a fotografia assume sua composição ficcional imanente e revela algo menos verdadeiro, talvez, mais desnudo?

Dá-se o clicke a fotografia surge como um estilhaço revolvido a leituras e cooptações intermináveis. Quando revis(i)tadas, certas fotografias fazemnos uma espécie de convite que transita do êxtase ao lirismo sempre que associada a emoções de um olhar carinhoso, apaixonado ou mesmo autodepreciativo. Afinal, quem são os mascarados a quem vemos envelhecer nos retratos? De quantos remendos a fotografia contemporânea é tecida? A arte fotográfica confronta o caos para dentro si? É possível trafegar contra a corrente e promover um gesto antifotográfico?

\section{O NARCISISMO E A PRÁTICA FOTOGRÁFICA CONTEMPORÂNEA}

Saímos à caça munidos de câmeras fotográficas em busca de novos cânones de beleza. Narcisicamente ${ }^{3}$ aprendemos a fotografar. Eis uma enxurrada contemporânea de selfies ${ }^{4}$. 0 belo parece ser a nossa própria imagem. Tentamos retê-la e publicá-la para todo o sempre. Fotografamos a beleza daquilo que construímos e/ou cultivamos como "o belo" - o nosso melhor ângulo - como se tivéssemos a obrigação de fazer um retrato por dia. Sontag (2004, p. 102) afirma que muitos se sentem nervosos quando vão ser fotografados: não porque receiem, como os primitivos, ser violados, mas porque temem a desaprovação da câmera. As pessoas querem a imagem idealizada: uma foto que as mostre com a melhor aparência possível.

Na mitologia Narciso morre afogado ao tentar abraçar o seu reflexo na água. Após sua morte, nasce ao lado do rio uma flor que recebe o nome de Narciso, em homenagem ao belo rapaz. Por isso adotamos o termo narcisismo para nos referirmos à devoção do ser humano sobre sua própria imagem. A psicanálise, através de Freud, acrescenta que a criança ao tomar sua própria imagem como objeto de adoração ou alvo de seu próprio amor, pode apresentar-se como narcisista ou alguém que se convence e até mesmo faz fantasias sobre si mesmo.

No narcisismo há uma preocupação exacerbada em manter-se jovem, com uma aparência impecável, especialmente no que tange o aspecto físico, externo, visível aos olhos. Isto é possível com a ajuda de um grande espelho. Espelho muitas vezes fotográfico, revelado por inúmeras postagens de selfs publicadas nas redes sociais e aplicativos, por exemplo numa tragi cultura narcísica contemporânea. Espelho/reflexo que na atualidade conta com sites de edição e manipulação em busca de nossa "melhor faceta".

O narcisista pode ser arrogante e não mostrar interesse naquilo que vem do Outro, mas, ao contrário, voltar a atenção e empenho para a gratificação de seu próprio eu. É difícil um narcisista se apaixonar pela imagem do Outro, há antes disso, a projeção da imagem própria no Outro e nas relações que se estabelecem. Se o reflexo 
dessa projeção não é a autoimagem, a relação estará sujeita ao descontentamento narcísico, pois Narciso se enamora do espelho por nele encontrar a representação da própria imagem.

No ensaio de Susan Buck-Morss ${ }^{5}$ (1996, p. 2729), intitulado: Estética e anestética: o "ensaio sobre a arte de Walter Benjamin" reconsiderado; a autora menciona que Jacques Lacan foi um dos precursores a se pronunciar sobre o estágio do espelho ou mais precisamente, quando uma criança de seis a dezoito meses consegue reconhecer e se identificar na imagem refletida - uma experiência narcísica diante do reflexo especular. A autora relembra que Hitler, por exemplo, fora orientado por Paul Drevient (cantor de ópera), a praticar diante de um espelho suas expressões faciais no desejo de encontrar o efeito apropriado de seus gestos.

O braço direito estendido é um cumprimento firme que, concomitantemente, saúda, estabelece distância e marca um gesto nazista. Gesto hierárquico, autoritário que espelha e acata a imagem refletida de um líder (reverenciado). Nas palavras de Buck-Morss (1996, p. 29) há razões para acreditar que este efeito não era expressivo, mas reflexivo, devolvendo ao homem-da-multidão a sua própria imagem - a imagem narcisista de um ego intacto, construído com o medo do corpo-em-pedaços.

A imagem de Narciso nos remete ao corpo sem órgãos ${ }^{6}$ de Deleuze. A criação do corpo sem órgão interrompe o corpo anestesiado estimulando-o a criar algo novo, mais intenso. Um corpo afetado que se percebe vivo, imerso a sensações e sentidos. Para Deleuze (1996, p. 15) o CsO é "campo de imanência do desejo, o plano de consistência própria do desejo".

No caso de Narciso, o reflexo de sua imagem abre um campo de possibilidades onde gozo e morte coabitam o mesmo espaço. Narciso deleita-se em seu espectro e contempla o próprio gozo. Há de um lado o movimento entre a testemunha e o gozo e, de outro lado, o olhar e o reflexo da imagem. A delicada linha que divide o reflexo e aquele que vê (Narciso), parece se configurar numa zona de risco onde o improvável pode acontecer.

Diante do espelho (a câmera fotográfica, o celular), Narciso admira, aproxima a sua mirada em busca daquilo que ainda não viu - o corpo, a súplica pelo gozo, o próprio desejo. 0 conjunto de práticas ou os modos deste corpo sem órgãos parece esquadrinhar outros jeitos de estar ali, de durar perante o reflexo os modos são tudo o que se passa: as ondas e as vibrações, as migrações, limiares e gradientes, as intensidades produzidas sob tal ou qual tipo substancial a partir de tal matriz (DELEUZE; GUATTARI, 2008, p.14).

Na pintura de Caravaggio (Narcissus, 15981599), por exemplo, notamos sutilmente o modo como Narciso procura o sensível, como deseja agarrar a beleza de seu rosto estampado nas águas. O corpo vibrante não se move, pois, qualquer gesto ríspido pode interromper o prazer contido naquele espetáculo. A imagem refletida é hipnotizante. Narciso está paralisado em pleno fascínio, exaltação e espasmo.

O reflexo é instigante na medida em que tira o corpo da inercia e promove novos agenciamentos, outras realidades e possibilidades em uma potência vital, em um arranjo de forças. Narciso teria se lançado nas águas a fim de apanhar o belo ou o espectro teria transbordado as margens seduzindo-o a ponto de induzi-lo a atirar-se no lago?

Eis um corpo que escapa, que suspira... onde o prazer começa e se finda. Neste jogo de espelhos, diante do arrebatamento absorvente da imagem, Narciso vê, cobiça e se apaixona por seu espectro. Narciso sofre ao contemplar a dança de sua imagem na superfície das águas. O fato de estar tão perto e tão distante faz com que ele se projete para dentro do espelho e nele encontre abrigo, ele mesmo e sua sombra (DELEUZE, 2007, p.25).

O espelho é um lago profundo e opaco onde o corpo submerge. Narciso ama a imagem. Seu espectro é um Outro tão real quanto a possibilidade do gozo entre ambos. O campo de imanência do desejo do CsO aparece na figura do fantasma projetado nas águas - o homem que Narciso toma por real - a intenção erótica é o amor de uma imagem, uma vibração e um gozo impossível de acontecer.

Assim como na mitologia, na música Sampa, Caetano Veloso, cantor e compositor brasileiro, 
faz uma metáfora a partir do mito de Narciso para mostrar seu sentimento ao olhar, pela primeira vez, a cidade de São Paulo:

[...] quando eu te encarei frente a frente não vi o meu rosto. Chamei de mau gosto o que vi, de mau gosto o mau gosto. É que Narciso acha feio o que não é espelho. E a mente apavora o que ainda não é mesmo velho. Nada do que não era antes quando não somos mutantes [...] [grifo meu].

Mas, se o Narciso acha feio o que não é espelho, na fotografia poderíamos partir de fragmentos para o registro de uma realidade inventada, imaginada. Se o rio interrompe seu fluxo e se torna espelho, Narciso é aprisionado ao reflexo. Poder-se-ia dizer que é um prisioneiro do novo Deus sol - a fotografia - para contemplar sua imagem trivial no metal (BAUDELAIRE, 1859). A magia e o encantamento estaria ligada a beleza do jovem rapaz, aos segredos contidos no reflexo e na verossimilhança?

Cabe lembrar que Baudelaire foi um teórico crítico de seu tempo sobre a arte. Quanto a fotografia produzida no século XIX, Baudelaire problematizava sua composição resistindo veemente a fragilidade do caráter estético das imagens que, para ele, eram inferiores a escultura e a pintura, embora fossem uma sedutora fonte de expressão.

Nos meados do século XIX, a fotografia tornouse popular. O mundo se mostrava mais íntimo. Os retratos revelavam paisagens desconhecidas e/ou contextos que antes eram anunciados pela narrativa escrita e pictórica. Pintores e artistas se sentiram ameaçados pelo processo de captura fotográfica. Temiam o fim da pintura ${ }^{7}$ e a falta de emprego. Muitos trataram de se apropriar da tecnologia moderna para atender a uma nova classe de clientes, sobretudo, nos grandes centros. Baudelaire, questionava a fotografia e os pintores modernos que aderiam facilmente ao invento.

Quando Baudelaire escreveu as cartas sobre o Salão da Acadêmica de Belas Artes da França, em 1859, adotou um tom de ironia para expressar sua insatisfação com a fotografia. No texto o público moderno e a fotografia o autor apresentou suas suspeitas sobre a representação do real. No escrito As flores do Mal, Baudelaire foi mais além e enfatizou que a decadência da arte na sociedade francesa tinha relação com a obstinação pela representação do real através da fotografia e, ainda, pela produção demasiada de imagens.

[...] como a indústria fotográfica foi o refúgio de todos os pintores fracassados, demasiado mal dotados ou preguiçosos para acabar seus estudos, esse deslumbramento universal teve não somente o caráter de cegueira e imbecilidade, mas também, a cor de uma vingança. Que uma tão estúpida conspiração, dentro da qual, como em todas as outras, encontramos os perversos e os equivocados, possa vencer de maneira absoluta, eu não acredito, ou pelo menos não gostaria de acreditar; mas estou convencido de que o progresso mal aplicado da fotografia muito contribuiu, como aliás todo progresso puramente material, para o empobrecimento do gênio artístico francês, já tão raro". (BAUDELAIRE, O público moderno e a fotografia, Carta ao Sr. Diretor da Revue Française sobre o Salão de 1859$)^{8}$.

As cartas foram encomendadas pela Revue Française. No fragmento abaixo podemos ver como Baudelaire dissemina sua frustração diante do Salão da Acadêmica de Belas Artes francesa:
[...] Meu caro Morel, quando o senhor me honrou pedindo-me a análise do Salão, disse-me: "Seja breve, não faça um catálogo, mas um arrazoado filosófico através das pinturas [...] O embaraço teria sido grande se eu me tivesse perdido numa floresta de originalidades, se o temperamento moderno francês, repentinamente modificado, purificado e rejuvenescido, houvessem dado flores tão vigorosas e de um perfume tão variado a ponto de criar uma comoção irrepreensível, se houvesse motivado elogios abundantes, uma admiração eloquente, e a necessidade de categorias novas dentro do idioma crítico. Mas de modo algum, felizmente (para mim). Nenhuma explosão, nada de gênios desconhecidos. Os pensamentos sugeridos pela aparência desse Salão são de uma ordem tão simples, tão antiga, tão clássica, que poucas páginas serão sem dúvida suficientes para desenvolvê-los (BAUDELAIRE, "O Artista Moderno", 1959).

Esperava-se que as galerias de Arte e os Salões, apresentassem grandes nomes e novas tendências da arte na França. Por isto, muitos intelectuais, artistas e curadores voltavam suas atenções às exposições ocorridas no século XIX. Entretanto, as propostas artísticas do século XX romperam com a antiga estrutura dos Salões de Arte para promover aquilo que conhecemos como Arte Moderna, fazendo com que as paredes e os espaços das galerias se tornassem algo quase sem estimação para a sociedade francesa. 
As cartas críticas de Baudelaire ganharam o cenário francês em 1859, embora tivessem sido escritas em 1845 e 1846. É curioso observar em sua trajetória que o encantamento e a aversão pela fotografia paradoxalmente caminharam lado a lado. Um exemplo é o desejo de Baudelaire em ter um retrato de sua mãe. Apesar disso, exigia que a fotografia fosse feita dentro de padrões estéticos defendidos nas cartas Salons ${ }^{10}$.

[...] Gostaria de ter seu retrato. É uma ideia que se apoderou de mim. Há um excelente fotógrafo em Hâvre. Mas temo que isso não seja possível agora. Seria necessário que eu estivesse presente. Você não entende desse assunto, e todos os fotógrafos, mesmo os excelentes, têm manias ridículas: eles tomam por uma boa imagem, uma imagem em que todas as verrugas, todas as rugas, todos os defeitos, todas as trivialidades do rosto se tornam muito visíveis, muito exageradas: quanto mais dura é a imagem, mais eles são contentes. Além disso, eu gostaria que o rosto tivesse a dimensão de duas polegadas. Apenas em Paris há quem saiba fazer o que desejo, quero dizer, um retrato exato, mas tendo o flou de um desenho. Enfim, pensaremos nisso, não?" (BAUDELAIRE, 22/12/186511).

Baudelaire se permitiu fotografar algumas vezes pelos fotógrafos Charles Neyt, Etienne Carjat e Nadar. Seria este outro exemplo de sua admiração pela fotografia? Estaria Baudelaire diante de um entusiasmo narcísico cuja crítica havia feito anteriormente nos Salons? Diante da contemplação de sua própria imagem Baudelaire dizia: caso não tenha destruído esse clichê, façame algumas cópias dele. Algumas! Quer dizer quantas você puder (BAUDELAIRE, 6/10/1863) ${ }^{12}$.

Embora Baudelaire tenha se mostrado bastante conservador ao escrever sobre a fotografia, seu trabalho manifesta a busca pela inovação artística francesa. Enquanto crítico sua função era desconfiar das técnicas atribuídas ao campo da representação artística. Nisto, desde a criação do daguerreótipo ${ }^{13}$, observava a tentativa humana por registrar detalhes da realidade não capturados pela pintura. No entanto, seria ingênuo pensar a fotografia como um documento incontestável e representativo do real. Baudelaire temia a consagração banal desta representatividade. Para ele, "uma obra não pode ser ao mesmo tempo artística e documental, pois a arte é definida como aquilo mesmo que permite escapar do real" (DUBOIS, 1993, p. 30).
Rouillè (2009, p. 59-60) ao citar uma passagem de Baudelaire sobre a ocasião do Salão de 1859 menciona a recusa de Baudelaire, sobre a fotografia, que deseja ferir o público, surpreendê-lo, choca-lo, sem deixa-lo elaborar o lento trabalho da memória, nem aflorar o domínio do impalpável e do imaginário". Para Baudelaire fotografia era desprovida de aura/ alma. As fotografias são irremediavelmente inseparáveis do real, enquanto arte tenta alcançar o ideal.

É verdade que as contribuições de Baudelaire sobre a fotografia podem ter sido precipitadas e que o tom irônico de sua crítica seja questionado, mas, seus ensaios possibilitam pensar como a disseminação imagética é vigente e como consolida uma nova cultura atravessada pela fotografia. Vivemos o culto às imagens, mas o que fazemos com isto?

É interessante pensar ainda sobre o clichê e o fetiche das imagens, mais precisamente sobre o processo de reificação das imagens. Aumont (1995, p. 129) aponta que tudo pode ser fetichizado, inclusive uma imagem. A magia, o encantamento, o interesse e a excitação que uma fotografia pode originar nos convoca a estudar a relação entre o real e o imaginário, a cognição e o desejo, de modo a superar a falência dos clichês, como sugere Deleuze (1990, p.31):

[...] um clichê é uma imagem sensório-motora da coisa. Como diz Bérgson, nós não percebemos a coisa ou a imagem inteira, percebemos sempre menos, percebemos apenas o que estamos interessados em perceber, ou melhor, o que temos interesse em perceber, devido a nossos interesses econômicos, nossas crenças ideológicas, nossas exigências psicológicas.

A fotografia pode abrigar o fetiche e o clichê. Como sabemos existe nos espaços artísticos, nos museus de arte contemporânea, nas instalações e intervenções urbanas, certa estética erótica, certo fetiche, certo clichê. Camille Paglia (1993, p. 24) declara que para projetar alguma coisa para uma câmera, deve-se ter autonomia auto-erótica, aguda autoconceitualização e até mesmo perversidade fetichista: a câmera é uma máquina com a qual se faz amor.

Neste sentido, e pensando especialmente na questão do clichê e do fetiche da imagem, podemos ainda considerar a experiência do 
voyeur que, ao observar uma fotografia, pode (ou não) aceitar seu convite; pode (ou não) jogar com a intencionalidade do fotógrafo e com a potência da imagem. É o imaginário do leitor que arriscará novas leituras e significações, ou como anuncia Deleuze, (1990, p. 18) olhar imaginário faz do real algo imaginário, ao mesmo tempo em que, por sua vez, se torna real e torna a nos dar realidade.

Como vimos, cada época é marcada por sua evolução tecnológica. Desde o seu surgimento a fotografia se tornou um instrumento de comunicação que permite ao ser humano daguerreotipar e documentar sua existência - consequentemente produzir visualidades. A propagação fotográfica consegue caracterizar povos, espaços, territórios, atividades comerciais, militares, escolares estabelecendo assim uma antropologia visual, além de democratizar a arte e incentivar o consumo de imagens em múltiplas dimensões.

\section{UMA APOSTA NA E-DUCAÇÃO DO OLHAR}

Carecemos ultrapassar o simples ato de passar os olhos por uma fotografia, para o ato de ver, isto é, de investigar a imagem, examinar os detalhes, numa visão mais esquadrinhada das coisas - um novo modo de ver (e capturar) temas já conhecidos àquilo que Sontag (2004) vai classificar como o heroísmo da visão ${ }^{15}$. Neste sentido, a proposta de Masschelein (2008, p. 36) sobre de e-ducar o olhar nos lança em um movimento de conduzir para fora, dirigir-se para fora, levar para fora. E-ducar não significa adquirir uma visão crítica ou liberada, mas sim libertar nossa visão. Vai além de um estímulo aos olhos, mas de fato propõe olhar atentamente aquilo que vê, tomar consciência de algo, transver o mundo. E-ducar é uma prática onde o sujeito pode trans-formarse, por isso requer pesquisa e deslocamentos (físico e mental). Para o autor, e-ducar o olhar significaria um convite a caminhar.

O percurso também é importante, mas é o caminhar que nos expõe a acontecimentos que se dão na medida em que se anda. Caminhar desacomoda o corpo, desassossega os olhos. No caminhar projetamos nossos olhos para janelas/paisagens e, mesmo as paisagens já conhecidas, podem ganhar outras nuances. Quando olhos livres (de qualquer julgo) percorrem o que se põe visível, podem deslocar e experimentar diferenças. Não é um evento que deseja apenas ultrapassar os limites da própria visão, mas alcançar a experiência proposta por Benjamin ${ }^{15}$ pelo olhar. Um olhar capaz de nos transformar, nos ex-por, nos lançar para fora de um determinado ponto de vista.

Olhar pode ir além de uma perspectiva já que toda perspectiva se prende ao ângulo de um sujeito ou de uma subjetividade. Quando fotografamos, produzimos visualidades, nosso olhar fragmenta uma cena, um texto, um contexto, transmite algo sobre aquilo que vemos e nos provoca a pensar sobre aquilo que não vemos. Fotografamos e, ao mesmo tempo, imprimimos o nosso olhar na imagem. Olhamos uma fotografia e também somos afetados pelo olhar do fotógrafo. Na relação com a captura vemos o que nela está presente-ausente. Qual é a força de uma fotografia? 0 que aprendemos com ela? O que nela é evidente?

Se $e$-ducar o olhar perpassa a entrega do sujeito aos atravessamentos que se dão transversalmente pelo olhar, não se trata de ler criticamente uma imagem, por exemplo, mas, oportunizar deslocamentos do olhar para ver, ou como diria Masschelein (2008, p. 39) ver aquilo que é evidente [...] trata-se de estar ou tornar-se atento ou expor-se. Uma relação que se estabelece com o espaço e o tempo presente. Um movimento que não necessariamente parte de um ponto para se chegar a outro, ao contrário, não existe um ponto de partida ou de chagada. O que existe é o caminho, a caminhada. É a caminhada que excita o deslocamento do olhar e nos pede a pensar sobre nós mesmos, sobre quem somos, onde estamos, que experiências vivenciamos... um pensamento que não se localiza exclusivamente em uma área ou ponto de vista particular, por isso, um pensamento transversal.

[...] pode-se dizer que caminhar é a atividade física de deslocar o olhar (ou seja, deixar uma posição, ex-posição) ao longo de uma linha arbitrária, um trajeto que ao mesmo tempo existe (e é recapturado) e abre caminho para novos olhares (sem levar, portanto, a um lugar anteriormente determinado, mas a um caminho sem destino ou orientação) (MASSCHELEIN, 2008, p. 39).

A crítica que tanto enfatizamos na educação está ligada ao posicionamento do sujeito, um exercício de expor-se, emancipar-se, descobrir 
a sua autonomia. Não é uma crítica que defende um conhecimento específico, mas uma prática de libertação. Isto é, não se refere apenas à conscientização do sujeito em torno de algo, mas proporciona que ele se manifeste sobre o presente, não para julgá-lo, mas para exibir seus próprios limites, num movimento de transformação de si e do próprio presente.

Assim, para se alcançar a crítica que, aqui tem a mesma intencionalidade da e-ducação do olhar pontuada por Masschelein, é preciso entender que não somos expectadores distantes de conteúdos e paisagens. Para se estabelecer relações entre o olhar e-ducado e o cotidiano, tomamos consciência das coisas e dos fatos entendendo que uma reflexão crítica libera o olhar de representações e julgo. Ou seja, repudiamos qualquer forma de valor e verdade. Suspendemos a análise para nos colocar à espera de algo; experimentamos o presente por ele mesmo. Não representamos o presente, mas o apresentamos no sentido de projetar o olhar para o estar atento de Masschelein.

[...] estar atento é abrir-se para o mundo. Atenção é precisamente estar presente no presente, estar ali de tal forma que o presente seja capaz de se apresentar a mim (que ele se torne visível, que eu possa ser transformado ou "atravessado" ou contaminado, que meu olhar seja liberado (pelo "comando" daquele presente). Pois tal atenção torna a experiência possível (MASSCHELEIN, 2008, p. 42).

É o caráter paradoxal da fotografia que interessa de imediato para além de sua materialidade. É a probabilidade de movimentos e perspectivas intermináveis que retém nossa atenção. Não me preocupa acompanhar a propagação sem escalas da fotografia, mas, encontrar meios de interromper o gesto do click para uma reflexão mais densa sobre o ato fotográfico em si. E, neste sentido, entender a fotografia enquanto uma tessitura de discursos (ato político) capaz de instituir os modos de como tecemos (ou não) as concepções imagéticas na sociedade atual. A arte fotográfica convoca a circular àquilo que não se dá a ver.

Sugiro observar a fotografia como texto. Texto feito de luz, de encenação, de manipulação, de desejos... A fotografia é um vestígio que deixa rastros para o imaginário. Dubois (2007, p. 268269) diz que a foto é também um verdadeiro material, um dado icônico bruto, manipulável como qualquer outra substancia concreta (recortável, combinável, etc). Sabemos que a fotografia é polissêmica e capaz de produzir em nós a expansão de sentidos e significações. Então, que tipo de prazer está contido no click fotográfico? Um tipo de fetiche que move o olhar voyeur? Se realidades e ficções estão presentes na fotografia, é a partir desta ambiguidade que refletimos sobre a produção de visualidades. Eis a fissura onde morte e vida coexistem e se sobrepõe como em camadas de parcelas de tempo. Um platô, que pode se deslocar e comunicar algo ainda não dito.

Quando produzimos fotografias, traçamos linhas, contornos, fabulamos universos, fabricamos sentidos que se intercalam às nossas vivências cotidianas. A imagem extravasa sua materialidade corpórea e nos pede a ver coisas, revela algo que noutro instante parecia despercebido. Miramos certas fotografias e passamos a pensar por imagens. Ítalo Calvino (1990) fala de uma possível Pedagogia da imaginação, um processo de experiência sensível que dá visibilidade e voz aos nossos pensamentos (devaneios, desejos, abstrações, representações culturais, etc). o olhar surge como uma ponte entre as sinapses biológicas, a fabricação de imagens e sentidos e a proposta de uma pedagogia da imaginação. Barthes (1984) completa este pensamento e nos provoca ao dizer que as imagens tem o desafio de despertar a imaginação de quem olha, lançar o observador no terreno fértil da imaginação lugar de criação e leituras mais amplas sobre as coisas e o mundo.

Se a fotografia é capaz de tecer memórias daquilo que somos e daquilo que nos sustenta, talvez seja a hora de lidar diretamente com a desconstrução da imagem, a desmontagem da captura, o desmanchar do próprio olhar (político/performático), o deslocamento da imagem pensante. Pensar a fotografia enquanto espaço aberto ao entrecruzamento da Arte e da Vida. A fotografia aparece como uma cadeia complexa de práticas artísticas que requer um pensamento mais denso sobre sua própria desmontagem. Pensar sobre o processo de desmontagem das representações é, de certo modo, procurar a presença ausente (do 
fotógrafo e de outros eus) nas capturas que temos produzido. Gosto da ideia de despir o conceito de representação contido na imagem fotográfica. Parece haver aí um apelo para que o fotógrafo se mostre, para que voltemos a origem das ideias, dos esboços, dos roteiros, das pesquisas fotográficas... Quem é a presença oculta por trás da captura e qual sua relação com a cena capturada?

A fotografia pode ser uma tentativa de representação, que foge de uma imitação e/ou reprodução do real. Não se trata tão somente de perceber uma presença simbólica, semiótica e representacional contida na fotografia, mas atingir outros textos - visuais; corpóreos; sonoros; dançantes; documentais... Por si só, a fotografia evoca que o espectador testemunhe um acontecimento (real e/ou ficcional) e transcenda sua limitação provisória.

Na Era de Narciso e no fetichismo visual contemporâneo parece haver um entusiasmo demasiado pela aparência do real corporificado e presentificado pela via crucies da imagem. Mas, ao invés de representar uma realidade universal, as capturas efêmeras a que somos sobrepostos, parecem evocar realidades plurais. Exibem pontos de vista diferentes sobre uma dada totalidade e, de algum modo, mostram como os acontecimentos diários acabam por modificar o próprio modo como produzimos fotografias.

Ao problematizar a desmontagem da fotografia exponho a vontade por encontrar as hibridizações, os cruzamentos, as fronteiras e os rasgões contidos nos rituais da imagem contemporânea e, concomitantemente, questionar os territórios da arte, da política, da poética, da ética e da estética fotográfica. Além do mais, ao desnudar a fotografia, talvez seja possível descobrir exposições do imaginário, frutos do desejo (individual e/ou coletivo), o desclausuramento de presenças que não necessariamente tenham sido capturadas com um fim artístico. O intento se revela então por extrapolar a estrutura da fotografia para conhecer outros modos de produção da imagem, seus deslocamentos e efeitos. Afinal, o que nos impulsiona a narrar algo?

\section{NOTAS}

01. SONTAG, 2004, p. 22.

02. Disponível em: <http://www.periodicos. ufsc.br/index.php/nelic/article/view/1581> acesso 15/04/13.

03. Caberia reler o Mito de Narciso da mitologia greco-romana.

04. Selfie significa autorretrato. Refere-se a uma foto tirada pela própria pessoa e/ou grupo para ser compartilhada nas redes sociais como Facebook e Instagran, por exemplo. Para se capturar uma selfie a pessoa não precisa de um bom equipamento fotográfico, basta usar a câmera de um aparelho celular, tablet ou webcam.

05. Travessias - Revista de Literatura, n.33. UFSC - Ilha de Santa Catarina, ago-dez. 1996; 11-41.

06. Termo usado por Gilles Deleuze em AntiÉdipo (1972) e Mil-Platôs (1980, vol.3), também conhecido como (CsO).

07. "No momento em que o Daguerre conseguiu fixar as imagens da câmera obscura, os técnicos substituíram, nesse ponto, os pintores. Mas a verdadeira vítima da fotografia não foi a pintura de paisagem, e sim o retrato em miniatura. A evolução foi tão rápida que por volta de 1840 , a maioria dos pintores de miniaturas se transformaram em fotógrafos" (BENJAMIN, 1994, p. 97).

08. ENTLER Ronaldo. Retrato de uma face velada: Baudelaire e a fotografia. FACOM - n) 17 - 1) semestre de 2007. Disponível em: <http:// www.entler.com.br/textos/baudelaire2.html > acesso em 29 de maio de 2012.

09. Idem.

10. Referente ao Salão de Belas Artes da França de 1859.

11. Idem.

12. Idem.

13. Aparelho inventado por Louis Jacques Mandé Daguerre (1787 - 1857), responsável pelo princípio de fixação e imagens de melhor qualidade. A invenção foi levada ao público na França, no dia 19 de agosto de 1839. "Em 1839, a invenção de Nièpice-Daguerre é solenemente 
anunciada e em seguida oferecida pela França "liberalmente ao mundo todo", enquanto a Inglaterra reivindica a paternidade. Sem apresentar um real interesse, essa primeira querela sublinha, todavia, que a fotografia surge quase simultaneamente na França e na Inglaterra, na "era do maquinismo" e no seu epicentro" (ROUILLÉ, 2009, p. 32).

14. "A fotografia inaugurou um novo modelo de atividade autônoma - ao permitir que cada pessoa manifeste determinada sensibilidade singular e ávida. [...] o momento apropriado é aquele em que se consegue ver coisas (sobretudo aquilo que todos já viram) de um modo novo. A busca tornouse a marca registrada do fotógrafo na imaginação popular [...] o que é belo tornou-se apenas aquilo que o olho não consegue ver (ou não vê): a visão fraturante, deslocadora, que só a câmera proporciona" (SONTAG, 2004, p. 106-107).

15. BENJAMIN, Walter. Rua de Mão Única. In: Obras escolhidas. Trad. R. Rodrigues Torres Filho e J. C. Martins Barbosa. São Paulo: Brasiliense, 2010. v. 2.

\section{REFERÊNCIAS}

AUMONT, Jacques. A imagem. Campinas, Papirus, 1993.

BARTHES, Roland. A Câmara Clara: nota sobre a fotografia. Rio de Janeiro: Nova Fronteira, 1984.

BAUDELAIRE, George. o público moderno e a fotografia. Carta ao Sr. Diretor da Revue Française sobre o Salão de 1859.

BENJAMIN, Walter. Obras Escolhidas, v. II, Rua de mão única, trad. de R.R. Torres F. e J.C.M. Barbosa, São Paulo: Brasiliense, 1987.

BUCK-MORSS, Susan. Estética e anestética: o "ensaio sobre a arte de Walter Benjamin" reconsiderado $I n$ : Travessias - Revista de Literatura, n.33. UFSC - Ilha de Santa Catarina, ago-dez. 1996; 11-41.

CALVINO, Italo. Seis propostas para o próximo milénio; Lisboa: Teorema, 1990. Trad.José Colaço Barreiros.
DELEUZE, G. Francis Bacon: Lógica da Sensação. Rio de Janeiro: Jorge Zahar. 2007.

DELEUZE, G. A imagem-tempo. São Paulo: Brasiliense, 1990, p.18.

DELEUZE, G. e GUATTARI, F. O que é a Filosofia? Tradução: Bento Prado Jr e Alberto Alonso Munoz. São Paulo, SP: Editora 34, 1992.

DELEUZE, Gilles; GUATTARI, Felix. Mil Platôs: capitalismo e esquizofrenia 2. Vol. 1 / Gilles Deleuze, Félix Guattari; tradução de Ana Lúcia de Oliveira, Aurelio Guerra Neto e Celia Pinto Costa. São Paulo: Ed. 34, 1995. V. 1.

DUBOIS, Phillipe. 0 ato fotográfico. Campinas: Papirus, 1993.

MASSCHELIEN, Jan. E-ducando o olhar; a necessidade de uma pedagogia pobre. Educação \& Realidade, v. 33, n. 1, p. 35-48, 2008.

PAGLIA, Camille. Sexo, arte e cultura americana. São Paulo, Cia das letras, 1993, p.24.

ROUILLÈ, André. A fotografia: entre documento e arte contemporânea. Tradução Costancia Egrejas - São Paulo: Editora Senac São Paulo, 2009.

SONTAG, Susan. Sobre Fotografia/ Susan Sontag; tradução Rubens Figueiredo. São Paulo: Companhia da Letras, 2004.

VELOSO, Caetano. Sampa. Interprete: Caetano Veloso. Ano: 1978.

\section{SOBRE A AUTORA}

Amanda M. P. Leite é fotógrafa, pesquisadora e professora na Universidade Federal do Tocantins. Graduada em Pedagogia pela Universidade Estadual de Mato Grosso; Mestre e Doutora em Educação pela Universidade Federal de Santa Catarina; Pós-Doutoranda em Educação pela Universidade Estadual de Campinas.

Contato: amandaleite@uft.edu.br - Site: http:// amandampleite.wixsite.com/amandaleite 